\title{
Design, Validation, and Application of a Questionnaire on Media Education for Teachers in Training
}

\author{
Julio-César Mateus ${ }^{1 *} \odot$, Wilson Hernández ${ }^{2}$ (๑) \\ 'Department of Communication, Universitat Pompeu Fabra, Spain \{julio.mateus@upf.edu\} \\ 2Institute of Scientific Research (IDIC), University of Lima, Peru \{whernan@ulima.edu.pe\} \\ Received on 7 June 2018; revised on 18 June 2018; accepted on 1 October 2018; published on 15 January 2019
}

DOI: 10.7821/naer.2019.1.329

(c) BY-NC-ND

\begin{abstract}
This article details the process of design, validation and application ( $\mathrm{N}=501)$ of an ad-hoc questionnaire that measures Peruvian teachers' knowledge, attitudes, and reasoning in training on media education. With regards to the method, several psychometric validation techniques were applied and the results were analyzed using descriptive statistics. The results showed a high level of internal coherence and confidence in the construct. Limited knowledge of the subject was found in the participants, without observing significant differences between the variables, and a very positive assessment of its importance and urgency. To conclude, media education is transversal to different classifications and interest in it is homogeneous throughout the teaching staff in training.
\end{abstract}

KEYWORDS: EDUCATION ABOUT MEDIA, MEDIA EDUCATION, TEACHER COMPETENCIES, PREPARATORY TRAINING FOR TEACHERS, EDUCATIONAL TECHNOLOGY.

\section{INTRODUCTION}

Umberto Eco (2007), an Italian philosopher, narrated the story of a student who provokingly asked his teacher, "Excuse me, but in the age of the Internet, what do we need you for?" For Eco, the raison d'être of a teacher is to train, not inform: "It's true that the television shows what happens in Iraq, but why something always happens there, from the Mesopotamian civilization until now, and not in Greenland, is something that only school can explain." Presently, in addition to contextualizing media content, teachers are expected to be able to adapt it, produce new content and share it, as well as teaching how to analyze and appreciate it. For this to happen, they must receive solid media education (ME) that does not limit the media to the role of didactic aids - which corresponds more to the field of educational technology — but that they understand it as a legitimate object of study.

Undoubtedly, the infiltration of information and communication technologies in all aspects of our lives has created an unprecedented state of media coverage (Couldry \& Hepp, 2017); this impact is especially noticeable in school settings. However, the impact of media on the education system results not only from its material presence, but also from the flows and content that it entails. This comprises content that merges information

*To whom correspondence should be addressed:

Roc Boronat 138

08018, Barcelona, Spain with opinion, reality with fiction, or those usage mechanisms that schools usually reject, to, "dissociate the mind from the body, the rational from the emotional, the abstract from the perceptive, the consciousness of the unconscious" (Ferrés \& Masanet, 2017, p. 59). In this context, media education is vital to prepare teachers to promote in themselves and their future students the development of skills that allow them to interact with the media in a critical and creative manner.

This paper is interested in ME's place in teacher training. To that extent, it proposes an original instrument that allows diagnosing the levels of knowledge, attitudes, and reasoning of future teachers on this subject. Comprehending teacher perceptions of media education is extremely useful because this subjectivity, according to the literature, is a predictor of how they can utilize certain media approaches or strategies in the classroom (Kanadl,, 2017; Mateus, 2016; Pegalajar-Palomino, 2015; Tondeur, van Braak, \& Ertmer, 2017). Despite its importance, few instruments fulfill this purpose and those that exist tend to focus on the use of devices or exclusively on so-called digital competences (Tondeur et al., 2015).

Therefore, this study proposes an original diagnostic tool that aims to fill a gap in academic production. In addition to the design and validation of the instrument, we analyze some results of its application and check whether variables such as gender, place of birth, type of institution, concentration being studied, or years of study are significant. This input can be used, by public and private teacher training centers, to improve their curricula in this field, allowing educational policy designers to invent new methods to promote ME based on the weaknesses and opportunities found in various school scenarios.

\subsection{Media Education}

The research problem has an important historical background. The Grünwald Declaration, signed by a global group of experts in 1982, called on the education system to pay more attention to the media because it is ubiquitous in our lives (even before the Internet!). This document accused schools of being disinterested, causing, in its words, "a true barrier [that] separates the educational experiences proposed by these [formal and informal] systems and the real world" (UNESCO, 1982, p. 1). It also warned that in the near future, the reasons for providing ME, "urgent" in the 80 s, would be "overwhelming" due to technological development. The Paris Agenda, published 25 years later, recommended prioritizing initial teacher training, including theoretical and practical aspects, based on evidence of the impact of ICT on youth (UNESCO, 2007). 
Today, much is said about media prosumers, but little about how they train in formal environments and acquire those skills (García-Ruiz, Ramírez, \& Rodríguez, 2014). In contrast, recent studies show that the greatest amount of media capacity is best learned informally; there is "a cultural and technological gap between today's youth and a school system that has not evolved at the same pace as society and its digital environment" (Scolari, 2018, pp. 9-10). In addition, various aphorisms, such as the "digital native," have led many teachers and policymakers to believe that students have innate conditions for media interaction, so it is not necessary to further this training (Kirschner \& De Bruyckere, 2017, p. 137).

There are certain capacities that ME can develop (Ferrés \& Piscitelli, 2012). Though there is no consensus about what they are - or whether we should call them media, digital, or informational - there are sufficient frames of reference, such as the Media and Information Literacy Curriculum for Teachers (UNESCO, 2011) or the European Framework for Digital Competence of Educators (Redecker, 2017). In Latin America, many of the national curricula already incorporate the technological dimension, but they do so excluding traditional media, ignoring a more ecological view of the media or from a position centered on usage (Mateus \& Muro, 2017; Romano, 2017).

\subsection{How Should Media Education Be Measured?}

Instruments measuring the perception of $\mathrm{ME}$ in teachers are scarce, which can be explained given the immeasurable number of dimensions available in literature, to the point that it would take too many years of effort to develop a truly comprehensive instrument (Hobbs, 2010). There are, however, abundant tools that measure skills (media or digital), but these tools view media as teaching aids and not as objects of study. In this regard, several authors have insisted on the importance of developing and empirically validating new instruments (Simons, Meeus, \& T'Sas, 2017).

Those consulted to develop this questionnaire have three characteristics in common: knowledge of ME, attitudes or perceptions around it, and reasoning that justifies its importance in school. Yates (1997) designed and applied the first in the United States and found material reasons (i.e., lack of time or didactic resources) and professional reasons (i.e., poor preparation received in their initial training) as the main problems in integrating ME in school. A decade later, Lauri, Borg, Günnel, and Gillum (2010) designed and applied another similar instrument to teachers from England, Malta, and Germany, where ME is part of the basic curriculum. Although participant interest was high, they concluded that not many had received optimal training, so they felt less confident regarding their media capabilities, especially in the field of content production. Moreover, the study Media Education: From passive consumers to active creators 2014-2016, funded by the European Commission, applied another questionnaire in Slovakia, Portugal, Greece, Italy, and Spain and determined the need to promote ME more intensely, as it is still largely unknown among teachers. The aforementioned study also reported that one third of teachers who said they applied ME in their schools did so more due to personal motivation rather than due to an institutional or curricular incentive (European Media Education Lab, 2017).

In Latin America, a significant interest in improving education quality, especially in the light of international test results such as PISA, has been observed (Rivas, 2015). This has led states to make large investments in hardware purchases and measure their impact as a means to compensate for the deficiencies in the educational service (Lugo \& Brito, 2015). Similarly, several studies have been developed that evaluate media competence in students, although they do so from frames of reference that are not always clear and divergent (Henriquez-Coronel, Gisbert, \& Fernández, 2018). However, we did not find studies that address ME in the initial teacher training stage, which gives our study greater novelty and relevance.

\section{METHOD}

\subsection{Study Objectives}

The objectives of this study were as follows: (i) to design and validate an instrument to evaluate $\mathrm{ME}$ in a population of teachers in training; (ii) to analyze the knowledge, attitudes, and reasoning that teachers in training have of ME; and (iii) to analyze whether there are significant differences in the results according to the teacher's gender, their place of birth, the type of institution where they are trained, their concentration, and their years of study.

\subsection{Participants}

The total sample comprised 501 students who were Education majors in their second to fifth year with concentrations in initial, primary, and secondary education. The sample was collected in the following three private institutions and one public institution in the city of Lima: Pontifical Catholic University of Peru (28\%), Cayetano Heredia Peruvian University (21\%), Ruiz de Montoya University (9\%), and the Monterrico National Pedagogical Institute $(42 \%)$. The data is not nationally representative, which is not an objective we sought. Instead, these four institutions were chosen on the basis of a more important criterion - that they have institutional certification. Three of the four universities and the only accredited pedagogical institute in Lima were covered. In that sense, our sample is representative of the teacher training institutions that meet this requirement. Participant ages varied between 18 and 42 years old $(\mathrm{A}=22, \mathrm{SD}=2.46)$. Although the sample was concentrated in institutions in the capital, $36 \%$ of the participants were born in another city, an aspect that supports our study given that it introduces variability in our sample.

Table 1. Sample Structure

\begin{tabular}{ll}
\hline \multicolumn{1}{c}{ Variables } & Sample $(\mathbf{N}=\mathbf{5 0 1})$ \\
\hline Sex & $86 \%$ \\
Women & $14 \%$ \\
Men & \\
Place of Birth & $36 \%$ \\
Born outside of Lima & $64 \%$ \\
Born in Lima & \\
Institution & $42 \%$ \\
Institute & $58 \%$ \\
University & \\
Concentration & $30 \%$ \\
Initial & $41 \%$ \\
Primary & $29 \%$ \\
Secondary &
\end{tabular}

\subsection{Instrument}

Taking the instruments previously reviewed as reference, an instrument was designed to measure the perceptions of teachers in training called "Questionnaire on Media Education Knowledge, 
Attitudes and Reasoning" (CAR-EM, for its Spanish acronym). The instrument included 15 items (Table 2). A Likert scale of five points was used based on levels of acceptance for each item $(1=$ strongly disagree and $5=$ strongly agree $)$. In addition, demographic and other useful data were collected (i.e., sex, age, place of birth, year in major, and concentration). The items were organized around three dimensions: (i) knowledge of ME (four items), with the purpose of evaluating the degree of proximity to the term, its presence in the country, as well as the value of the specialized training received in their major; (ii) attitudes on ME in teacher training (five items), to assess their predisposition toward the subject, its training characteristics, and the perceived barriers to its implementation; and (iii) reasons for integrating ME in schools (six items), to explore their foundations for believing (or not) that it should be carried out in the classroom.

Prior to the psychometric validation phase, the questionnaire was submitted to five independent judges who are experts in ME. After this first phase, various validation strategies were applied.

Table 2. Dimensions and Items of the CAR-EM Questionnaire

\begin{tabular}{|c|c|c|}
\hline Dimensions & & Items \\
\hline \multirow{4}{*}{$\begin{array}{l}\text { Knowledge of } \\
\text { ME (CON) }\end{array}$} & 1 & $\begin{array}{l}\text { I know what media education (ME) is and I can } \\
\text { define it }\end{array}$ \\
\hline & 2 & $\begin{array}{l}\text { I have received training in ME as part of my } \\
\text { teacher training }\end{array}$ \\
\hline & 3 & $\begin{array}{l}\text { The ME training I received is sufficient to } \\
\text { integrate it into my teaching }\end{array}$ \\
\hline & 4 & $\begin{array}{l}\text { I know institutions, policies, or projects that } \\
\text { promote ME in my country }\end{array}$ \\
\hline \multirow{5}{*}{$\begin{array}{l}\text { Attitudes on } \\
\text { ME in teacher } \\
\text { education }\end{array}$} & 1 & ME should be mandatory in all teacher training \\
\hline & 2 & $\begin{array}{l}\text { Teacher training in ME must be specific (i.e., be } \\
\text { present in one or more exclusive courses within } \\
\text { the curriculum) }\end{array}$ \\
\hline & 3 & $\begin{array}{l}\text { ME in schools must be equally present at } \\
\text { all school levels (i.e., initial, primary, and } \\
\text { secondary) }\end{array}$ \\
\hline & 4 & $\begin{array}{l}\text { The lack of initial teacher training in ME topics } \\
\text { is a barrier to teacher development }\end{array}$ \\
\hline & 5 & $\begin{array}{l}\text { Limited or complete lack of access to media in } \\
\text { schools is a barrier to ME development }\end{array}$ \\
\hline \multirow{6}{*}{$\begin{array}{l}\text { Reasons to } \\
\text { Integrate ME } \\
\text { into Schools }\end{array}$} & 1 & To empower students as critical citizens \\
\hline & 2 & To motivate students \\
\hline & 3 & To customize student learning \\
\hline & 4 & To expand learning experiences \\
\hline & 5 & $\begin{array}{l}\text { To facilitate the transmission of curriculum } \\
\text { content }\end{array}$ \\
\hline & 6 & To train students in a key competency \\
\hline
\end{tabular}

\subsection{Data Analysis}

The internal consistency of the instrument was evaluated using Cronbach's Alpha statistics and the Homogeneity Index (item-total correlation), which allowed us to evaluate the variation of the variances when eliminating each item. This overall evaluation was complemented with the validity for each of the instrument's three dimensions. Since the reliability achieved was high (0.8168), it was not necessary to perform additional procedures to identify how many additional items should be added to obtain a desired level of reliability (greater than 0.80 ).
Furthermore, the Kaiser-Meyer-Olkin (KMO) measures were estimated to evaluate the percentage of the variance that arises from the underlying factors evaluated. This measure was complemented with the Bartlett's test for sphericity to evaluate the relationship between items and to lead to tests that detect greater structure in the data. The construct validity was analyzed by confirmatory factor analysis, considering the existence of previous models. Several indicators were used to evaluate the goodness of fit (Chi2, Root Mean Squared Error of Approximation, Standardized Root Mean Squared Residual, Comparative Fit Index, and Non-Normed Fit Index). Finally, different discriminant validity tests were carried out, for which the total score of the questionnaire was contrasted between the first and last tertile (t-test). The data obtained was processed in Stata software version 14 .

\subsection{Process}

The questionnaire was applied to students from the four institutions participating in the study between September 15 and October 15, 2017. The instrument was self-administered and filled during class time. The students were informed about the instrument's purpose and were invited to participate anonymously and voluntarily. The rejection rate was low ( $1 \%$ approximately). One of this study's authors was responsible for applying the questionnaire, which lasted between 20 and 30 minutes.

\section{RESULTS}

The results are presented in two sections. The first section summarizes the psychometric validation analysis and the second uses descriptive statistics to analyze the results and use the most interesting differences between variables.

\subsection{Validation}

\subsubsection{Internal Consistency}

Based on all the items, the internal reliability test was performed with Cronbach's Alpha, obtaining good results (0.8168). The Homogeneity Index, based on the Pearson correlation, tested the Pearson correlation of the score between each item and the total of items. The values obtained are all positive and similar (i.e., homogeneous), which means the items do not measure something different from what the instrument as a whole measures.

Table 3 shows the descriptive statistics of each item. Very high mean values were not obtained in any of these cases (ceiling effect), which would have created problems of variability in the data.

The instrument's internal consistency produced good results (Cronbach's Alpha equal to 0.8168), under the George and Mallery qualification standard (2003). Consistency at the level of each of the three dimensions also had similar results (Table 4). As seen in Table 5, the KMO values demonstrated the adequacy of the sample. Their values were markedly higher than the standard of 0.50 (Pituch \& Stevens, 2016). In the same table, Bartlett's test for sphericity confirms that the data matrix structure is related, an aspect that opens the possibility of validating the construct through confirmatory factor analysis. All the items had loadings higher than 0.50. Similarly, the correlations between items of the same dimension suggest the existence of independent dimensions associated with a larger construct. The correlations in the CON dimension varied between 0.59 and 0.79 , those in the ACT dimension between 0.22 and 0.66 , and those in the RAZ dimension between 0.40 and 0.61 . 
Table 3. Descriptive Statistics of the CAR-EM Questionnaire

\begin{tabular}{rccccc}
\hline Variable & Obs & Mean & Std. Dev. & Min & Max \\
\hline CON - item 1 & 501 & 2.60 & 1.10 & 1 & 5 \\
CON - item 2 & 496 & 2.33 & 1.12 & 1 & 5 \\
CON - item 3 & 496 & 2.32 & 1.10 & 1 & 5 \\
CON - item 4 & 498 & 2.19 & 1.09 & 1 & 5 \\
ACT - item 1 & 497 & 3.94 & 1.00 & 1 & 5 \\
ACT - item 2 & 498 & 3.84 & 1.02 & 1 & 5 \\
ACT - item 3 & 497 & 3.80 & 1.03 & 1 & 5 \\
ACT - item 4 & 494 & 3.96 & 0.94 & 1 & 5 \\
ACT - item 5 & 495 & 3.96 & 0.99 & 1 & 5 \\
RAZ - item 1 & 499 & 4.29 & 0.80 & 1 & 5 \\
RAZ - item 2 & 499 & 4.43 & 0.69 & 1 & 5 \\
RAZ - item 3 & 499 & 4.18 & 0.84 & 1 & 5 \\
RAZ - item 4 & 498 & 4.40 & 0.73 & 1 & 5 \\
RAZ - item 5 & 497 & 4.22 & 0.81 & 1 & 5 \\
RAZ - item 6 & 497 & 4.16 & 0.87 & 1 & 5 \\
\hline
\end{tabular}

Table 4. Item-total Correlation of the Complete Instrument

\begin{tabular}{|c|c|c|c|c|c|c|}
\hline \multirow{3}{*}{ Item } & \multirow{3}{*}{ Obs } & \multirow{3}{*}{ Sign } & $\begin{array}{c}\text { item- } \\
\text { test }\end{array}$ & $\begin{array}{c}\text { item- } \\
\text { rest }\end{array}$ & Mean & \multirow{3}{*}{$\begin{array}{l}\text { Cron- } \\
\text { bach's } \\
\text { Alpha }\end{array}$} \\
\hline & & & $\begin{array}{c}\text { correla- } \\
\text { tion }\end{array}$ & $\begin{array}{c}\text { correla- } \\
\text { tion }\end{array}$ & $\begin{array}{c}\text { inter- } \\
\text { item }\end{array}$ & \\
\hline & & & & & $\begin{array}{l}\text { cova- } \\
\text { riance }\end{array}$ & \\
\hline $\begin{array}{l}\mathrm{CON}- \\
\text { item } 1\end{array}$ & 501 & + & 0.5730 & 0.4620 & 0.2005 & 0.8042 \\
\hline $\begin{array}{l}\mathrm{CON}- \\
\text { item } 2\end{array}$ & 496 & + & 0.5812 & 0.4700 & 0.1992 & 0.8035 \\
\hline $\begin{array}{l}\mathrm{CON}- \\
\text { item } 3\end{array}$ & 496 & + & 0.5751 & 0.4649 & 0.2005 & 0.8039 \\
\hline $\begin{array}{l}\mathrm{CON}- \\
\text { item } 4\end{array}$ & 498 & + & 0.4998 & 0.3727 & 0.2067 & 0.8100 \\
\hline $\begin{array}{l}\mathrm{ACT}- \\
\text { item } 1\end{array}$ & 497 & + & 0.6663 & 0.5820 & 0.1949 & 0.7948 \\
\hline $\begin{array}{l}\text { ACT - } \\
\text { item } 2\end{array}$ & 498 & + & 0.6022 & 0.5041 & 0.1994 & 0.8004 \\
\hline $\begin{array}{l}\mathrm{ACT}- \\
\text { item } 3\end{array}$ & 497 & + & 0.5769 & 0.4742 & 0.2015 & 0.8026 \\
\hline $\begin{array}{l}\mathrm{ACT}- \\
\text { item } 4\end{array}$ & 494 & + & 0.4817 & 0.3774 & 0.2115 & 0.8097 \\
\hline $\begin{array}{l}\mathrm{ACT}- \\
\text { item } 5\end{array}$ & 495 & + & 0.4594 & 0.3459 & 0.2123 & 0.8121 \\
\hline $\begin{array}{l}\text { RAZ - } \\
\text { item } 1\end{array}$ & 499 & + & 0.4526 & 0.3620 & 0.2162 & 0.8102 \\
\hline $\begin{array}{l}\text { RAZ - } \\
\text { item } 2\end{array}$ & 499 & + & 0.5214 & 0.4486 & 0.2146 & 0.8062 \\
\hline $\begin{array}{l}\text { RAZ - } \\
\text { item } 3\end{array}$ & 499 & + & 0.4989 & 0.4071 & 0.2124 & 0.8078 \\
\hline $\begin{array}{l}\text { RAZ - } \\
\text { item } 4\end{array}$ & 498 & + & 0.4834 & 0.4034 & 0.2161 & 0.8085 \\
\hline $\begin{array}{l}\text { RAZ - } \\
\text { item } 5\end{array}$ & 497 & + & 0.4539 & 0.3617 & 0.2161 & 0.8104 \\
\hline $\begin{array}{l}\text { RAZ - } \\
\text { item } 6\end{array}$ & 497 & + & 0.5045 & 0.4110 & 0.2113 & 0.8074 \\
\hline Total & & & & & 0.2075 & 0.8168 \\
\hline
\end{tabular}

Table 5. Kaiser-Meyer-Olkin Measure and Bartlett's Test for Sphericity

\begin{tabular}{lcccc}
\hline & CON & ACT & RAZ & Total \\
\hline KMO & 0.828 & 0.693 & 0.872 & 0.8383 \\
Barlett: & & & & \\
Chi2 & 1,139 & 703 & 1,136 & 3,093 \\
$\begin{array}{l}\text { Degrees of } \\
\text { Freedom }\end{array}$ & 6 & 10 & 21 & 105 \\
p-value & 0.000 & 0.000 & 0.000 & 0.000 \\
\hline
\end{tabular}

\subsubsection{Confirmatory Factor Analysis}

The results of the confirmatory factor analysis are presented in Table 6. Varimax rotation was used to better capture the contribution of each item to its respective dimension. We worked with loadings greater than 0.50 to capture the relationship between each item and its dimension in a more exacting manner. Pituch and Stevens (2016) observe that the 0.40 threshold ensures a strong association between the item and the dimension evaluated. We observed that the items in each dimension contribute to independently measure what was predicted from the theory. This is especially important because the communalities and the number of items in each dimension produce good estimators when the sample is 200 observations (Fabrigar, Wegener, MacCallum, \& Strahan, 1999). Our sample contained 501 observations, further strengthening the results.

Table 6. Confirmatory Factor Analysis

\begin{tabular}{lcccc}
\hline & CON & ACT & RAZ & Uniqueness \\
\hline CON - item 1 & 0.76 & & & 0.40 \\
CON - item 2 & 0.87 & & & 0.25 \\
CON - item 3 & 0.85 & & & 0.27 \\
CON - item 4 & 0.73 & & & 0.46 \\
ACT - item 1 & & 0.71 & & 0.38 \\
ACT - item 2 & & 0.59 & & 0.56 \\
ACT - item 3 & & 0.51 & & 0.64 \\
ACT - item 4 & & 0.55 & & 0.66 \\
ACT - item 5 & & 0.53 & & 0.68 \\
RAZ - item 1 & & & 0.63 & 0.57 \\
RAZ - item 2 & & & 0.70 & 0.48 \\
RAZ - item 3 & & & 0.74 & 0.44 \\
RAZ - item 4 & & & 0.72 & 0.47 \\
RAZ - item 5 & & & 0.71 & 0.49 \\
RAZ - item 6 & & & 0.63 & 0.59 \\
\hline
\end{tabular}

\subsubsection{Goodness of Fit}

There is no single index to evaluate the confirmatory factor analysis goodness of fit. In this sense, what Table 7 shows are different indices that allow us to make an overall conclusion about the suitability of what is evaluated.

The values of the Chi2 test indicate that a model with more relationships between the items is preferable (p-value less than 0.05). However, this result is an indication of the more complex relationship between the different items of different dimensions, 
something that, in future research, studies analyzing the questionnaire predictors can be approached through structural equations with cross-relationships (for example, CON items influencing mutually, CON items influencing ACT or RAZ items, and vice versa). In addition, as noted by Mulaik et al. (1989), goodness of fit indices only provide the most fundamental evidence about a model's fit. Additionally, the CON and RAZ dimensions showed a satisfactory evaluation through the Root Mean Squared Error of Approximation, according to the MacCallum, Browne, and Sugawara standard (1996) set at $<0.10$. The two additional goodness of fit indices offer a similar conclusion. First, the Standardized Root Mean Squared Residual was lower than the standard set by $\mathrm{Hu}$ and Bentler (1999) at 0.08 in two of three dimensions (CON and RAZ). Second, the Comparative Fit Index was greater than 0.90 in two dimensions and close to the optimal limit in the third. A more demanding measure is that of the non-Normed Fit Index, which avoids the tendency to negative bias of the underlying Chi2 tests. In this case, a good adjustment is attributed when the value is greater than 0.95 , which is achieved in the CON and RAZ dimensions.

Table 7. Goodness of Fit Indices

\begin{tabular}{|c|c|c|c|c|c|}
\hline $\begin{array}{c}\text { Fit } \\
\text { statistic }\end{array}$ & Description & $\begin{array}{l}\text { Full } \\
\text { scale }\end{array}$ & CON & ACT & RAZ \\
\hline \multicolumn{6}{|c|}{ Likelihood ratio } \\
\hline \multirow[t]{2}{*}{$\operatorname{chi} 2$} & model vs. saturated & 299 & 3,886 & 138 & 42,246 \\
\hline & $\mathrm{p}>$ chi2 & 0 & 0 & 0 & 0 \\
\hline \multirow[t]{2}{*}{ chi2 } & $\begin{array}{l}\text { baseline vs. } \\
\text { saturated }\end{array}$ & 3,138 & 1,147 & 708 & 1,137 \\
\hline & $\mathrm{p}>$ chi2 & 0 & 0 & 0 & 0 \\
\hline RMSEA & $\begin{array}{l}\text { Root mean } \\
\text { squared error of } \\
\text { approximation }\end{array}$ & 0.072 & 0.044 & 0.233 & 0.086 \\
\hline CFI & $\begin{array}{l}\text { Comparative fit } \\
\text { index }\end{array}$ & 0.930 & 0.998 & 0.809 & 0.970 \\
\hline TLI & $\begin{array}{l}\text { Tucker-Lewis } \\
\text { index }\end{array}$ & 0.916 & 0.995 & 0.618 & 0.951 \\
\hline SRMR & $\begin{array}{l}\text { Standardized root } \\
\text { mean squared } \\
\text { residual }\end{array}$ & 0.061 & 0.011 & 0.107 & 0.032 \\
\hline
\end{tabular}

\subsubsection{Discriminant Validity}

The discriminant validity was evaluated by contrasting the total score between the first $(\mathrm{N}=178)$ and last tertile $(\mathrm{N}=149)$ to evaluate whether there were significant differences between groups and if we can conclude that the highest scores express a more positive perception toward ME (Table 8). Media contrast tests were conducted and significant differences were found in all the items $(p<0.01)$, preparing for the gradual adaptation of the score to measure perceptions of ME.

Additional tests were conducted to evaluate if the total score allowed us to distinguish other classifications (i.e., sex, institution, years of study, and concentration). This analysis forms part of the descriptive analysis presented below, wherein the ANOVA test, the Bonferroni test for multiple comparisons (i.e., contrast of the total score among the four teacher training institutions), and the Kruskal-Wallis test were used (i.e., for the same purpose as above, but applied when the evaluated variable did not follow a normal distribution).
Table 8. Contrast Tests of Means between First and Last Tertile

\begin{tabular}{|c|c|c|c|c|}
\hline Items & $\begin{array}{l}\text { 1st tertile } \\
\text { (mean) }\end{array}$ & $\begin{array}{l}\text { 3rd tertile } \\
\text { (mean) }\end{array}$ & Difference & Significance \\
\hline $\begin{array}{l}\mathrm{CON}- \\
\text { item } 1\end{array}$ & 1.96 & 3.40 & -1.44 & $* * *$ \\
\hline $\begin{array}{l}\mathrm{CON}- \\
\text { item } 2\end{array}$ & 1.66 & 3.24 & -1.59 & $* * *$ \\
\hline $\begin{array}{l}\mathrm{CON}- \\
\text { item } 3\end{array}$ & 1.62 & 3.17 & -1.55 & $* * *$ \\
\hline $\begin{array}{l}\mathrm{CON}- \\
\text { item } 4\end{array}$ & 1.59 & 2.88 & -1.29 & $* * *$ \\
\hline $\begin{array}{l}\text { ACT - } \\
\text { item } 1\end{array}$ & 3.25 & 4.57 & -1.32 & $* * *$ \\
\hline $\begin{array}{l}\mathrm{ACT}- \\
\text { item } 2\end{array}$ & 3.21 & 4.44 & -1.24 & $* * *$ \\
\hline $\begin{array}{l}\text { ACT - } \\
\text { item } 3\end{array}$ & 3.16 & 4.42 & -1.27 & $* * *$ \\
\hline $\begin{array}{l}\text { ACT - } \\
\text { item } 4\end{array}$ & 3.51 & 4.34 & -0.83 & $* * *$ \\
\hline $\begin{array}{l}\text { ACT - } \\
\text { item } 5\end{array}$ & 3.41 & 4.38 & -0.97 & $* * *$ \\
\hline $\begin{array}{l}\text { RAZ - } \\
\text { item } 1\end{array}$ & 3.94 & 4.64 & -0.70 & $* * *$ \\
\hline $\begin{array}{l}\text { RAZ - } \\
\text { item } 2\end{array}$ & 4.08 & 4.77 & -0.69 & $* * *$ \\
\hline $\begin{array}{l}\text { RAZ - } \\
\text { item } 3\end{array}$ & 3.79 & 4.56 & -0.77 & $* * *$ \\
\hline $\begin{array}{l}\text { RAZ - } \\
\text { item } 4\end{array}$ & 4.09 & 4.70 & -0.61 & $* * *$ \\
\hline $\begin{array}{l}\text { RAZ - } \\
\text { item } 5\end{array}$ & 3.88 & 4.56 & -0.68 & $* * *$ \\
\hline \multirow[t]{2}{*}{$\begin{array}{l}\text { RAZ - } \\
\text { item } 6\end{array}$} & 3.73 & 4.62 & -0.88 & $* * *$ \\
\hline & & & & $* * * \mathrm{p}<0.01$ \\
\hline
\end{tabular}

\subsection{Results of Descriptive and Inferential Statistics}

Now we will analyze the scores obtained after the application and will highlight their significant differences. The synthesis of these results can be seen in Table 9 below.

\subsubsection{Knowledge of Media Education (ME)}

In general, future teachers' knowledge of ME is very limited. In fact, it is the dimension where the participants scored the lowest. This finding confirms what Yates described with American students in his seminal study developed in 1997 and in the European Media Education Lab study (2017) a decade later. The situation is worse when we ask students if they have received training on the subject as part of their teaching training. The score of those who are more assured of having been trained increases slightly with years of study, while students not born in Lima reported having received better preparation than their peers. Also, far from the expected results, years of preparation are not positively correlated with greater confidence in the training received in ME. Here too, a difference persists in favor of students born outside of Lima.

Consistently, participants' knowledge of institutions, projects, or policies promoting ME in the country was very poor, which speaks of an environment that is not very interested in promoting this topic (or a serious communication problem, if we want to be more optimistic). In addition, students born outside of Lima indicated greater knowledge than their colleagues in the capital. 
Table 9. CAR-EM Questionnaire Score according to Key Variables

\begin{tabular}{|c|c|c|c|c|c|c|c|c|}
\hline & \multicolumn{2}{|c|}{ CAR-EM Index } & \multicolumn{2}{|c|}{$\mathrm{CON}$} & \multicolumn{2}{|c|}{ ACT } & \multicolumn{2}{|c|}{ RAZ } \\
\hline & Mean & SD & Mean & SD & Mean & SD & Mean & SD \\
\hline Total Score & 54.2 & 7.99 & 9.4 & 3.81 & 19.4 & 3.56 & 25.6 & 3.64 \\
\hline \multicolumn{9}{|l|}{ Sex: } \\
\hline Male & 54.6 & 7.13 & 10.2 & 3.74 & 19.1 & 3.47 & 25.3 & 3.30 \\
\hline Female & 54.2 & 8.17 & 9.2 & 3.82 & 19.5 & 3.59 & 25.7 & 3.69 \\
\hline \multicolumn{9}{|l|}{ Place of Birth: } \\
\hline Outside the capital & 54.3 & 7.67 & 9.8 & 3.81 & 19.5 & 3.38 & 25.1 & 3.66 \\
\hline In the capital & 54.2 & 8.17 & 9.1 & 3.79 & 19.4 & 3.67 & 25.9 & 3.61 \\
\hline \multicolumn{9}{|l|}{ School Grade: } \\
\hline $2 \mathrm{nd}$ & 53.1 & 8.37 & 9.0 & 3.65 & 18.9 & 4.03 & 25.3 & 4.06 \\
\hline $3 \mathrm{rd}$ & 55.3 & 6.86 & 10.6 & 3.84 & 19.9 & 2.93 & 25.1 & 3.26 \\
\hline 4 th & 53.9 & 8.8 & 8.8 & 3.77 & 19.5 & 3.65 & 26.2 & 3.58 \\
\hline 5 th & 56.1 & 6.42 & 10.0 & 3.93 & 20.1 & 2.63 & 26.1 & 2.96 \\
\hline \multicolumn{9}{|l|}{ Concentration: } \\
\hline Initial & 52.7 & 8.05 & 8.7 & 3.8 & 18.8 & 3.68 & 25.4 & 3.88 \\
\hline Primary & 53.9 & 7.95 & 9.4 & 3.69 & 19.1 & 3.55 & 25.7 & 3.71 \\
\hline Secondary & 56.3 & 7.58 & 10.1 & 3.89 & 20.5 & 3.25 & 25.8 & 3.31 \\
\hline \multicolumn{9}{|l|}{ Institution: } \\
\hline Institute & 55.3 & 7.16 & 9.4 & 3.86 & 19.9 & 3.25 & 26.2 & 3.2 \\
\hline University & 53.5 & 8.47 & 9.4 & 3.78 & 19.1 & 3.75 & 25.3 & 3.9 \\
\hline
\end{tabular}

Note: The CAR-EM index varies between 0 and 75. The higher the value, the better the perception of knowledge, attitudes, and ME. The CON dimension varies between 0 and 20, while the ACT dimension varies between 0 and 25 and the RAZ dimension varies between 0 and 30 .

\subsubsection{Attitudes on ME}

In the attitude dimension, respondents' perceptions were very favorable toward the need to receive ME. Almost three quarters of the participants indicated that they agreed or strongly agreed with the obligatory nature of this training for all teachers, significantly highlighting secondary school teachers compared to their peers in initial and primary education. This positive attitude toward ME coincides with that obtained in the aforementioned studies in the European context (Lauri, Borg, Günnel, \& Gillum, 2010).

Regarding characteristics that their ME should have, the participants pointed out that, first, it must be specific, that is, be present in one or more specific courses of the curriculum, and second, it is necessary at all levels of schooling (initial, primary, and secondary). In both items, significant differences are valued regarding opinions from institute students versus university students and students in the secondary concentration versus their colleagues in other concentrations.

On the other hand, among the barriers perceived to develop ME in school, the first was no or limited access to media, and second, the lack of initial training received. In this regard, it is important to note that the presence of ICT in Peruvian schools is very restricted: only $25 \%$ of schools have Internet, with $86 \%$ in operational status, and the student per computer ratio in primary and secondary school being 6 and 7 respectively. (Mateus \& Muro, 2016) According to a UNICEF report on Peruvian schools, the weakest point in ICT management policies has been the lack of a coherent, planned implementation perspective, aimed at achieving realistic and concrete objectives accompanied by adequate monitoring and evaluation processes (Balarín, 2013, p. 43).
Here, the only significant difference that emerges from the comparison of variables is relative to the level of concentration, with secondary school being the most categorical when showing their degree of agreement with both barriers.

\subsubsection{Reasons to Integrate Media Education in Schools}

Finally, we measured the reasons considered by future teachers concerning the integration of ME in schools. This is the dimension with the highest score, which is explained by the fact that all the premises are possible affirmations, although based on particular nuances. The purpose here was to measure which ones stood out. Of the six premises suggested from the literature consulted, the reason they agreed with most was to "motivate the students" and the least was "to train them in a key competence." We separated the reasons presented in two types: one focused on the object or external to the individual, such as "motivate," "expand," and "facilitate"), and others centered on the subject or internal to the individual, such as "empower," "customize," and "train." It is interesting to note that the best-valued are the first, in general terms, which unites the instrumental view of media reported in other studies.

Although no significant differences were found by gender, concentration, or year of study, some discrepancies in the analysis of responses for place of birth and type of institution did draw attention; teachers who are trained in the pedagogical institute were more categorical about the best reasons to integrate ME. Similarly, participants born in Lima were more emphatic in their agreement with the reasons "to expand learning experiences," "facilitate the transmission of curricular content," and "personalize student learning." 


\section{CONCLUSIONS}

The absence of instruments that measure the perception of ME in teachers in training makes it difficult to assess how they are prepared to practice their profession in a media-centric environment. Thanks to the use of quantitative validation techniques, we can present an instrument that fulfills this purpose. In this process, different strategies and techniques were used to evaluate internal consistency, the structure of data through the confirmatory factor analysis, its goodness of fit, and the discrimination of the score between groups with the lowest score. Unable to find other related instruments, we believe that the CAR-EM questionnaire represents a contribution to research in the field of ME.

Regarding the second objective, to analyze the knowledge, attitudes, and reasoning of teachers in training of ME, we can conclude, first, that there is a clear lack of knowledge on the topic, which coincides with that found in all the studies cited in this study. At the same time, it signifies a valuable opportunity for the development of projects and specialized courses. The concept of ME is ambiguous, unlike other concepts based on school tradition, such as math or art education. Much responsibility for this situation falls on academics and institutions that produce content on the subject, which is sometimes abstract or overly conceptual, that abuses different terminology and ends up confusing decision-makers and teachers themselves. We agree with Buitrago, García Matilla, and Gutiérrez Martín (2017) that it is preferable to use the term ME over others such as informational, digital, audiovisual, or communicative, as they are all contained in media.

Regarding future teachers' attitudes on ME, awareness of its importance is equally clear. In this sense, the questionnaire demonstrates the richness and complexity of the topic by itself. Future teachers' perceptions are that they require more specific treatment of ME in their curriculum and that it is relevant for all levels of schooling. It is also consistent that they mention the lack of technological resources they have in their schools as a significant barrier, since there is an infrastructure gap recognized by the Peruvian Ministry of Education itself, which adds very short-term management in the sector policies associated with ICT. We must insist on the need to offer a more comprehensive and cultural approach to media in teacher training, especially in initial training, since a negative appreciation of teachers' possibilities to learn how to utilize technology has led to leaving training aside and giving little importance to the role that teachers can and should play as facilitators and partners in children's learning using available technologies (Balarín, 2013, p. 42).

On the other hand, the reasons given by future students to integrate ME highlights a positive view, which is good, but with a tendency to conceive media preferentially as a teaching aid-useful to attract attention or facilitate the transmission of curricular content - rather than as objects of study. The reductionist risk of studying the means on the basis of usage and not conceiving other dimensions such as symbolic, ethical, or ideological is persistent. As Jesús Martín-Barbero (2009) noted, similar to that proposed by Couldry and Hepp, which was mentioned at the beginning, the role of culture in society changes when the technological means of communication cease to be merely instrumental to be enhanced, densified, and structural. That is the reason why, today, technology complies as much or more with a few devices to new ways of perception and language, as to new sensibilities and writings (p. 24).

Finally, with regards to the third objective, although we noted significant differences between variables in some dimensions, none were stable throughout the analysis of results, which leads us to conclude that ME is transversal to different classifications and interest toward it, which is homogeneous among teachers.

In the future, the questionnaire should be validated in other contexts, and its usefulness in other languages should be confirmed.

\section{REFERENCES}

Balarín, M. (2013). Las politicas TIC en los sistemas educativos de América Latina: Caso Perú. Buenos Aires: UNICEF. Retrieved from https://www.unicef.org/ argentina/spanish/Peru_ok.pdf

Buitrago Alonso, A., García Matilla, A., \& Gutiérrez Martín, A. (2017). Perspectiva histórica y claves actuales de la diversidad terminológica aplicada a la educación mediática. EDMETIC, 6(2), 81-104. doi:10.21071/edmetic.v6i2.7002

Couldry, N., \& Hepp, A. (2017) The Mediated Construction of Reality. Cambridge: Polity Press.

Eco, U. (21 de mayo de 2007) ¿De qué sirve el profesor? La Nación. Retrieved from http://www.lanacion.com.ar/910427-de-que-sirve-el-profesor

European Media Education Lab (2017). Media Education at Secondary Schools in Five European Countries. Teacher Survey Report. Retrieved from http://www. europeanmediaeducationlab.com/surveys.html

Fabrigar, L., Wegener, D., MacCallum, R., \& Strahan, E. (1999). Evaluating the Use of Exploratory Factor Analysis in Psychological Research. Psychological Methods, 4(3), 272-299. doi:10.1037/1082-989X.4.3.272

Ferrés, J., \& Masanet, M. (2017). La eficacia comunicativa en la educación: potenciando las emociones y el relato. Comunicar, 52, 51-60. doi:10.3916/C522017-05

Ferrés, J. \& Piscitelli, A. (2012). La competencia mediática: propuesta articulada de dimensiones e indicadores. Comunicar, 38, 75-82. doi:10.3916/C38-2012$02-08$

García-Ruiz, R., Ramírez, A., \& Rodríguez, M. M. (2014). Educación en alfabetización mediática para una nueva ciudadanía prosumidora. Comunicar, 43 , 15-23. doi:10.3916/C43-2014-01

George, D., \& Mallery, P. (2003). SPSS for Windows step by step: A simple guide and reference 11.0 update $\left(4^{\circ}\right.$ ed.). Boston: Allyn y Bacon.

Henriquez-Coronel, P., Gisbert, M., \& Fernández, I. (2018). La evaluación de la competencia digital de los estudiantes: una revisión al caso latinoamericano. Chasqui. Revista Latinoamericana de Comunicación, (137), 93-112 doi:10.16921/chasqui.v0i137.3511

Hobbs, R. (2010). Digital and Media Literacy: A Plan of Action (white paper). Washington D.C.: The Aspen Institute.

Hu, L. T., \& Bentler, P. M. (1999). Cutoff criteria for fit indexes in covariance structure analysis: Conventional criteria versus new alternatives. Structural equation Modeling, 6(1), 1-55. doi:10.1080/10705519909540118

Kanadl1, S. (2017). Prospective teachers' professional self-efficacy beliefs in terms of their perceived autonomy support and attitudes towards the teaching profession: A mixed methods study. Educational Sciences: Theory y Practice, 17 1847-1871. doi:10.12738/estp.2017.5.0597

Kirschner, P. A., \& De Bruyckere, P. (2017). The myths of the digital native and the multitasker. Teaching and Teacher Education, 67, 135-142. doi:10.1016/j. tate.2017.06.001

Lauri, M. A., Borg, J., Günnel, T., \& Gillum, R. (2010). Attitudes of a sample of English, Maltese and German teachers towards media education. European Journal of Teacher Education, 33(1), 79-98. doi:10.1080/02619760903414124

Lugo, M. T., \& Brito, A. (2015). Las políticas TIC en la educación de América Latina. Una oportunidad para saldar deudas pendientes. Archivos de Ciencias de la Educación, 9(9), 1-16.

MacCallum, R. C., Browne, M. W., \& Sugawara, H.M. (1996). Power analysis and determination of sample size for covariance structure modelling. Psychological Methods, 1(2), 130-149. doi:10.1037/1082-989X.1.2.130

Martín-Barbero, J. (2009). Cuando la tecnología deja de ser una ayuda didáctica para convertirse en mediación cultural. Teoría de la Educación. Educación y Cultura en la Sociedad de la Información, 10(1), 19-31.

Mateus, J. C. (2016). Abrumados y fascinados: Las TIC en la subjetividad de los docentes peruanos. Redes, (12), 170-193. doi:10.15213/redes.n12.p170

Mateus, J. C., \& Muro, E. (2016). Competencias TIC: una estrategia para invertir en tecnología educativa. In Metas del Perú al Bicentenario (pp. 183-190). Lima: Consorcio de Universidades. doi:10.13140/RG.2.2.17988.83840

Mulaik, S., James, L., Van Alstine, J., Bennett, N., Lind, S., \& Stilwell, D. (1989). Evaluation of goodness-of-fit indices for structural equation models. Psychological Bulletin, 105(3), 430-445. doi:10.1037/0033-2909.105.3.430

Pegalajar-Palomino, M. C. (2015). Diseño y validación de un cuestionario sobre percepciones de futuros docentes hacia las TIC para el desarrollo de prácticas inclusivas. Píxel-Bit. Revista de Medios y Educación, 47, 89-104. doi:10.12795 pixelbit.2015.i47.06

Pituch, K., \& Stevens, J. (2016). Applied Multivariate Statistics for the Social Sciences ( $6^{\mathrm{a}}$ ed.). Nueva York: Routledge. 
Redecker, C. (2017). European Framework for the Digital Competence of Educators: DigCompEdu. Luxemburgo: Oficina de Publicaciones de la Unión Europea. doi: $10.2760 / 159770$

Rivas, A. (2015). América Latina después de PISA: Lecciones aprendidas de la educación en siete países (2000-2015). Buenos Aires: CIPPEC-Natura-Instituto Natura.

Romano, M. B. (2017). Educación y medios en la escuela secundaria argentina: la mirada de los estudiantes. Actualidades Investigativas en Educación, 17(3), 1-33. doi:10.15517/aie.v17i3.29109

Scolari, C. A. (2018) El proyecto de investigación Transmedia Literacy. En C. A. Scolari (Ed.), Adolescentes, medios de comunicación y culturas colaborativas: aprovechando las competencias transmedia de los jóvenes en el aula. Barcelona: Universitat Pompeu Fabra. Retrieved from http://hdl.handle. net $/ 10230 / 34245$

Simons, M., Meeus, W., \& T'Sas, J. (2017). Measuring Media Literacy for Media Education: Development of a Questionnaire for Teachers' Competencies. Journal of Media Literacy Education, 9(1), 99-115.

Tondeur, J., Aesaert, K., Pynoo, B., van Braak, J., Fraeyman, N., \& Erstad, O. (2015). Developing a validated instrument to measure preservice teachers' ICT competencies: Meeting the demands of the 21 st century. British Journal of Education Technology, 48(2), 462-472. doi:10.1111/bjet.12380

Tondeur, J., van Braak, J., Ertmer, P. A., \& Ottenbreit-Leftwich A. (2017). Understanding the relationship between teachers' pedagogical beliefs and technology use in education: a systematic review of qualitative evidence. Educational Technology Research and Development, 65(3), 555-575. doi:10.1007/s11423016-9481-2

UNESCO. (1982). Declaración de Grünwald sobre la Educación relativa a los medios de comunicación. Retrieved from http://www.unesco.org/education/pdf/ MEDIA S.PDF

UNESCO. (2007). Agenda de París. Retrieved from https://www.diplomatie.gouv. fr/IMG/pdf/Parisagendafin_en.pdf

UNESCO. (2011). Currículum para profesores sobre Alfabetización Mediática e Informacional. Retrieved from http://unesdoc.unesco.org/images/0021/002160/216099s.pdf

Yates, B. (1997). Media Education's Present and Future: A Survey of Teachers. Birmingham: National Media Literacy Citizenship Project's Summer Conference.

How to cite this article: Mateus, J.-C., \& Hernández, W. (2019). Design, Validation, and Application of a Questionnaire on Media Education for Teachers in Training. Journal of New Approaches in Educational Research, 8(1), 34-41. doi:10.7821/naer.2019.1.329 